\title{
Studies on combining ability and gene action for yield and quality traits in Baby corn (Zea mays L.)
}

\author{
Hemlata Kumari $^{*}$, Nikhil Kumar ${ }^{2}$, Mukesh Kumar ${ }^{3}$ and Rashmi Kumari ${ }^{1}$ \\ ${ }^{1}$ Department of Plant Breeding and Genetics, Bihar Agricultural University, Sabour, Bhagalpur- 813210 (Bihar), INDIA \\ ${ }^{2}$ Department of Agronomy, Bihar Agricultural University, Sabour, Bhagalpur-813210 (Bihar), INDIA \\ ${ }^{3}$ Department of Seed Science and Technology, Bihar Agricultural University, Sabour, Bhagalpur-813210 (Bihar), INDIA \\ *Corresponding author. E-mail: hemalata.sabour@gmail.com
}

Received: October 16, 2015; Revised received: May 11, 2016; Accepted: July 25, 2016

\begin{abstract}
An investigation was carried out to assess the combining ability and nature of gene action in baby corn (Zea mays L.) genotypes, by making crosses of eight inbred lines namely, HKI 3209, SML 1, EC 595979, CM 128, VQL 1, G 18 seq C5 F 76-2-2-1-1-2-BBB, HKI 209, in diallel mating design (without reciprocal crosses) by following Griffing Model-I and Method-II during rabi season 2013-14 at the experimental farm of BAC, Sabour, Bhagalpur (Bihar). The crosses were evaluated in a randomized complete block design (RCBD) to assess the combining ability and nature of gene action. Based on general combining ability, parents CM 128 and VQL 1 were best parent for breeding programme for yield and quality improvement. The specific combining ability also indicates that hybrid CM128 x VQL1 was best specific combiner for baby corn yield $(4.11 \mathrm{q} / \mathrm{ha})$, fodder yield $(50.91 \mathrm{q} / \mathrm{ha})$ as well as for better quality. The crosses CM 128 x HKI 209 recorded the high mean (7.35\%) and SCA effects (2.57 ${ }^{\circ}$ Brix) for quality traits. The gene action analysis also revealed preponderance of non-additive gene action for yield and its contributing characters.
\end{abstract}

Keywords: Baby corn, Combining ability, Gene action, Quality traits

\section{INTRODUCTION}

Maize (Zea mays L.), is the third most important cereal crop in the world. It has been cultivated for centuries as a grain crop and more recently it becoming very popular as vegetables, such as baby corn (Zea mays var. saccharata) (Muthukumar et al., 2005; Mahajan et al., 2007).

Baby corn is very delicious, decorative and nutritious vegetable rich in fibrous protein which is easy to digest and low calorific vegetable. It is grown for its young, fresh, finger like green ears, harvested at the time of silk emergence and before pollination and fertilization (Ramachandrappa et. al., 2004). Light yellow colour baby corn ears with regular row arrangement, 10 to 12 $\mathrm{cm}$ long and diameter of 1.0 to $1.5 \mathrm{~cm}$ are preferred in the market (Muthukumar et al., 2005). India is emerging as one of the potential baby corn producing countries. Among the Indian states, Rajasthan is first in respect of area, where this crop occupies area, production and productivity 10.5 lakh ha, 19.5 lakh tones, $18.6 \mathrm{q}$ $\mathrm{ha}^{-1}$ respectively (Government of Rajasthan, 2010).

The production areas of baby corn (Zea mays L.) are still confined to a few countries, including Thailand, Indonesia, India, and Brazil. Baby corn production and improvement on the part of the breeders has resulted in the development of number of varieties. Even though, there was no much works had been done (Chauhan et. al., 2010). For exploring the potential yield and good quality baby corn harvest, we need to explore the standard heterosis. The development of new hybrids for the exploration of heterosis depends on the combining ability of the lines or varieties involved in the production of these hybrids. It is a known fact that selection of parents on the basis of their mean performance does not necessarily lead to desired results (Rai and Asati, 2011). Therefore, devising a sound breeding strategy to improve the yield and quality traits of this crop is of paramount importance. Combining ability analysis help breeders in choosing suitable genotypes as parents for hybridization and superior cross combinations through GCA and SCA studies, respectively (Rodrigues and da Silva, 2002; Rai and Asati, 2011) and at the same time, it also elucidates the nature and magnitude of different types of gene action involved, which is essential for an effective breeding program. Hence, this investigation was undertaken to study the estimates of general and specific combining ability and gene action in baby corn (Zea mays L.) for yield components and quality characters.

\section{MATERIALS AND METHODS}

Experimental material: The present experiment was carried out at BAC Farm of Bihar Agricultural University, Sabour, Bhagalpur (Bihar), during rabi 2013-14 and kharif 2014. The eight genetically diverse baby corn inbreds viz., HKI 3209, SML 1, EC 595979, CM 
128, VQL 1, G 18 seq C5 F76-2-2-1-1-2-BBB, HKI 209 , were crossed in diallel mating design following Model-I, Method-II of Griffing (1956) during rabi 2013-14 (Table 1). The commonly used method of combining ability analysis that includes one way crosses and their parents without reciprocal crosses (Singh and Narayanan, 1993).

Experimental methods: The parents and their resulting $28 \mathrm{~F}_{1} \mathrm{~s}$ were raised in a Randomized Complete Block Design (RCBD) with 3 replications during kharif 2014. Each plot consisted 2 rows of each $5 \mathrm{~m}$ in length and spacing between rows and plants were 60 $\mathrm{cm}$ and $20 \mathrm{~cm}$, respectively. Two seed per hill were planted to ensure the optimum population and recommended package of practices were followed to raise a healthy crop (Crop production guide, 2012). The twelve observations were taken such as 1 .Randomly 10 plants basis- Plant height (PHT), Number of leaves per plant (NOL), Number of Baby corn /plant (NBC), Baby corn length (BCL), 2. Plant basis- Days to $50 \%$ tasseling (DFT), Baby corn yield (BCY), Fodder yield (FY). 3.Bulk baby corn sample of each entry and each replication basis- Total soluble solid (TSS) was estimated by hand refrectometer in Brix , Total sugar (TS), Reducing sugar (RS) and Non reducing sugar (NRS) was determined by Nelson and Somoygi (1944), Crude protein (CP) was estimated by the MicroKjeldhal method (AOAC, 1970). Mean data were subjected for analysis of general combining ability (GCA), specific combining ability (SCA) and gene action as per method given by Griffing (1956) (method II and model I) using the software WINDOSTAT(version 7.1).

\section{RESULTS AND DISCUSSION}

Analysis of variance for combining ability revealed that mean sum of squares of GCA \& SCA for yield and yield contributing trait and quality characters were highly significant for all the characters presented in

Table 1. Parental lines used for diallel mating and its sources.

\begin{tabular}{|c|c|c|c|}
\hline $\begin{array}{l}\text { S. } \\
\text { N. }\end{array}$ & Parents & $\begin{array}{l}\text { Name of the } \\
\text { parents }\end{array}$ & Sources \\
\hline 1 & P1 & HKI 3209 & KARNAL, HISAR \\
\hline 2 & P2 & SML 1 & BAU, SABOUR \\
\hline 3 & P3 & EC 595979 & CIMMYT, MEXICO \\
\hline 4 & P4 & CM 128 & DMR, NEW DELHI \\
\hline 5 & P5 & VQL 1 & $\begin{array}{l}\text { ALMORA , UT- } \\
\text { TRAKHAND }\end{array}$ \\
\hline 6 & P6 & $\begin{array}{l}\text { G } 18 \text { seq C5 F76 } \\
-2-2-1-1-2-B B B\end{array}$ & CIMMYT, MEXICO \\
\hline 7 & P7 & HKI 209 & KARNAL, HISAR \\
\hline 8 & P8 & $\begin{array}{l}\text { DTPYC-F38-5- } \\
2-1-1-2-2-1-B 4\end{array}$ & CIMMYT, MEXICO \\
\hline 9 & $\mathrm{C}_{1}$ (Check) & VL Baby corn 1 & $\begin{array}{l}\text { ALMORA , UT- } \\
\text { TRAKHAND }\end{array}$ \\
\hline 10. & $\mathrm{C}_{2}$ (Check) & G5414 & $\begin{array}{l}\text { ADVANTA INDIA } \\
\text { LTD. }\end{array}$ \\
\hline 11. & $\mathrm{C}_{3}$ (Check) & HM4 & KARNAL, HISAR \\
\hline
\end{tabular}

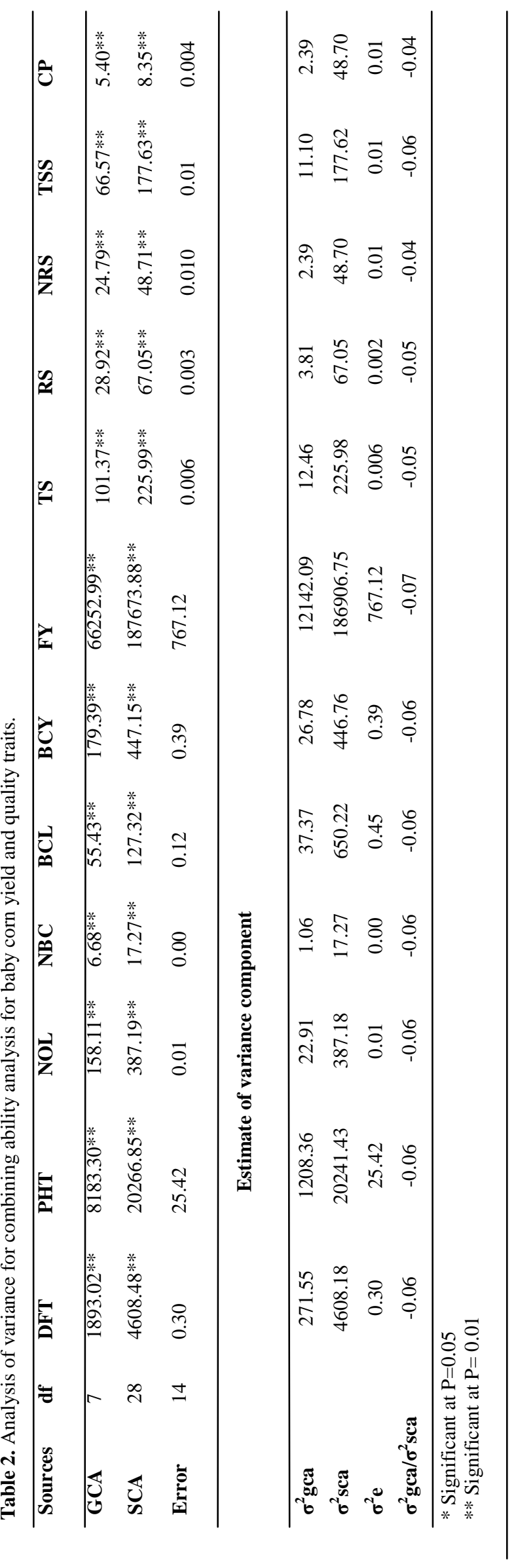




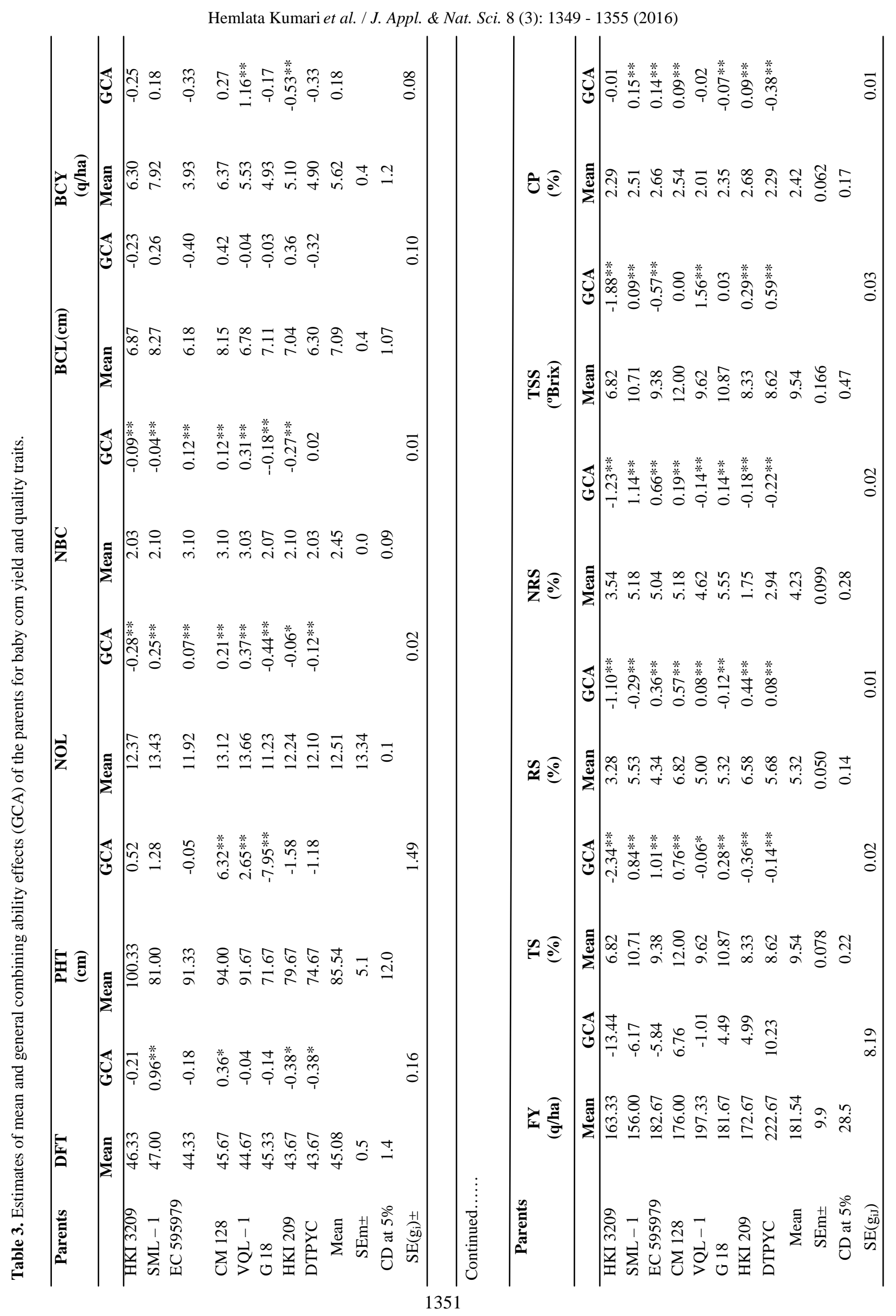


Hemlata Kumari et al. / J. Appl. \& Nat. Sci. 8 (3): 1349 - 1355 (2016)

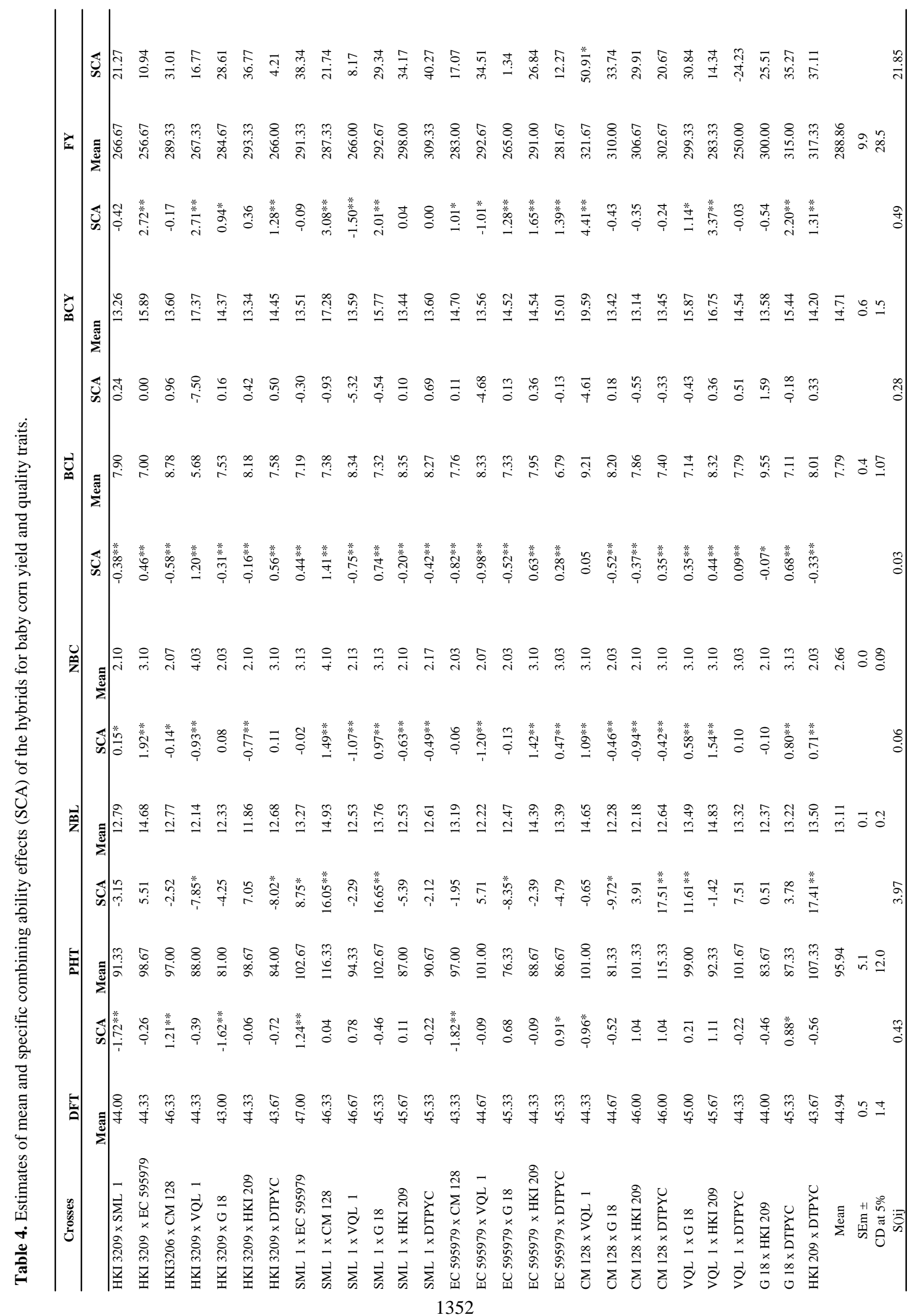




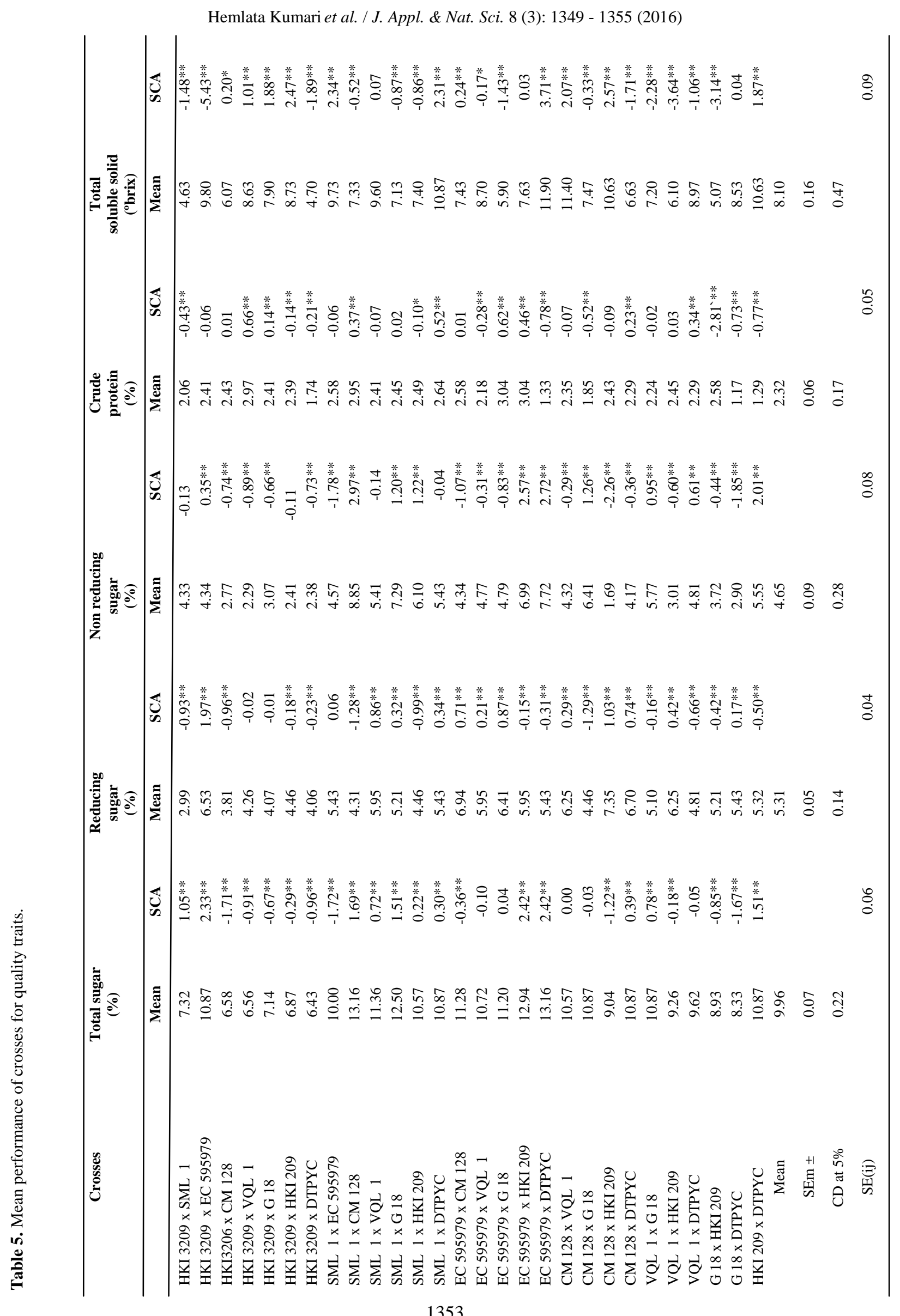


Table 2 under studied. The mean squares of SCA were larger than those of GCA in all the characters. It was also reveled that preponderance of non-additive gene action involved in control of the characters. The importance of non additive gene actions were also confirmed by the findings of Anantha (2004) and Selvarani (2007) for days to tasseling, Geetha and Jayaraman (2000), Anantha (2004) and Prakash and Ganguli (2004) for plant height, Jayakumar and Sundaram (2007) for number of leaves per plant, Rodrigues and da Silva (2002) for baby corn length and Suneetha et al. (2000) for non reducing sugars in baby corn which is in agreement with our finding.

The high positive estimates of specific combining ability in absolute values indicates that hybrid performance is relatively superior or inferior to parent lines general combining ability, showing the importance of additive interactions resulting from the complementation degree among parent lines in relation to frequency of alleles in loci with some dominance, while low estimates of specific combining ability in absolute value indicates that hybrids behave as expected in relation to general combining ability of parent lines (Vencovsky and Barriga, 1992). In the selection of parent lines used to produce hybrids, the effect of a specific combining ability analyzed in an isolated way has a limiting value. Thus, other parameters should be considered such as and general combining ability of the respective parent lines (Oliveira et al., 1998). The parent CM 128 and VQL 1 under present investigation were the best among eight parents shows desirable mean and GCA effect for yield, yield attributing traits and quality traits. So, these parents could be used extensively in hybrid breeding programme to increase baby corn yield and quality. Similar to present investigation were also reported by Dhasarathan et al. (2012) in baby corn for selection of suitable parental line for exploiting heterosis. Therefore, superior hybrid combinations, which are important for breeding, are involved with at least one parental line which has the most favorable effects of general combining ability (Cruz and Regazzi, 1997). Thus, it is possible to analyze the hybrids that showed high performance for most of the yield (baby corn yield and fodder yield) and quality traits (T.S.S, T.S) such as CM128 x VQL1 and VQL1 x HKI209 (Table 4). Baby corn yield per plot in the hybrid CM128 $\mathrm{x}$ VQL1 is associated with high effects of general combining ability of both the parent lines. Therefore, in this case, the high productivity is not due to dominant genetic effects of inbred but due to additive effects. In the VQL1 x HKI209 hybrid is associated with high effect of the general combining ability of the VQL1 (BCY) and HKI209 (FY) inbred with one of highest effect of the estimated specific combining ability, since HKI209 inbred showed lower general combining ability. In this case, the participation of specific combining ability is significant for yield, contribution almost to the general combining ability from both inbreds, regarding the dominance and epistasis effect (Gardner, 1963). However, the hybrid G18 x HKI209 and SML1 x CM128 exhibited highest specific combining ability for baby corn length and number of baby corns per plant and CM 128 x HKI 209 (reducing suger and total soluble solid) showed highest specific combining ability effect. About 5 hybrids exhibited higher mean performance and SCA effects for baby corn yield per plot. In respect of baby corn superiority, it is decided by its quality. Hence, the crosses CM128 x VQL1 and CM 128 x HKI 209 recorded the high mean and SCA effects for yield and quality traits of baby corn.

\section{Conclusion}

The present study concluded that CM128 \& VQL1 were the best among the all eight parents as it showed desirable mean and GCA effects for most of the yield, yield contributing traits and quality traits of baby corn ear, respectively. Therefore these genotypes could be used extensively in hybrid breeding program with a view to increase baby corn yield with quality traits. Furthermore, based on mean and SCA effects, the one hybrid CM128 x VQL1 was found suitable for baby corn yield with better quality. For varietal improvement, these crosses could also be utilized for exploiting promising recombinants and it could be useful towards enhancing baby corn yield and quality.

\section{REFERENCES}

Anantha, M.S. (2004). Combining ability and molecular diversity analysis in maize inbreds. M.Sc. (Ag.), Thesis, Tamil Nadu Agricultural University, India. AOAC. (1970). Official method of analysis of Association of official Analytical Chemists 11th Ed., Washington, D.C. p. 815.

Chauhan, S.K. and Mohan, J. (2010). Estimates of variability, heritability and genetic advance in baby corn. Indian J. Hort. 67 (Special Issue): 238-241.

Crop Production Guide (2012). Department of Agriculture, Government of Tamil Nadu and Tamil Nadu Agricultural University, Coimbatore

Cruz, C.D.and Regazzi, A.J. (1997). Modelos biometricos aplicados ao melhoramento genetic. Imprensa universitaria, Vicosa. SABRAO J. Breed. Geneicst. 47 (1) 60-69.

Dhasarathan M, Babu C, Iyanar K and Velayudham K (2012) Studies on genetic potential of baby corn (Zea mays L.) hybrids for yield and quality traits. Electronic Journal of Plant Breeding. 3: 853-860.

Gardner, C.O. (1963). Estimates of genetic parameters in cross fertilizing plants and their importance in plant breeding. In: Hanson WD, Robinson HF, editors. Statistical genetics and plant breeding. Natl. Acad. Sci. Natl. Res. Counc. Publ. Washington, pp. 225-252.

Geetha, K.and Jayaraman (2000). Genetic analysis of yield in maize. Madras Agric. J., 87(10-12): 638-640.

Government of Rajasthan (2010). Vital Agricultural Statistics, Directorate of Agriculture, Jaipur, Rajasthan. Griffing, B. (1956). Concept of general and specific 
combining ability in relation to diallel crossing system. Australian J. Biol. Sci. 9: 463-98.

Jayakumar, J. and Sundaram, T. (2007). Combining ability studies for grain yield and other yield components in maize (Zea mays L.). Crop Research, 33 (1, 2, \& 3) : 179-186.

Mahajan, G.R.; Sharda, A.K. and Singh, K.G. (2007). Effect of plastic mulch on economizing irrigation water and weed control in baby corn sown by different methods. African journal of Agriculture Research , 2 (1) : 19-26.

Muthukumar, V.B.; Velayudham and Thavaprakaash N. (2005). Growth and yield of baby corn (Zea mays L.) as influenced by plant growth regulators and different time of nitrogen application. Res. J.Agric. Biol. Sci., 1 (4) : 303-307.

Nelson, N. and Somoygi, M. (1944). A photometric adoption of the Somogyi's method for determination of glucose.J. Biol. Chem. 153: 375-378.

Oliveira, V.R.; Casali V.M.D.; Cruz, C.D; Pereira, P.R.G. and Scapim, C.A. (1998). Capacidae de combinacao entre linhagens de pimentao diferindo na tolerancia ao baixo teor de fosforo no solo. Bragantia. 57: 203-214.

Prakash, S. and Ganguli, D.K. (2004). Combining ability for various yield component characters in maize (Zea mays L.). Journal of Research (BAU), 16 (1): 55-60.
Rai, N. and Asati, B.S. (2011). Combining ability and gene action studies for fruit yield and yield contributing traits in brinjal. Indian J. Hort. 68 (2): 212-215

Ramachandrappa, B. K.; Nanjappa, I. I. V. and Shivakumar, I. I. K. (2004). Yield and quality of baby corn (Zea mays L.) as influenced by spacing and fertilization levels. Acta Agronomica Hungarica, 52 : 237-243.

Rodrigues, L.R.F. and da Silva, N. (2002). Combining ability in baby corn inbred lines (Zea mays L.). Crop Breeding and Applied Biotechnology 2 (3): 361-368.

Selvarani, E. (2007). Studies on combining ability of fodder maize (Zea mays L.) and sweet corn (Zea mays L. Saccharata) for evolving dual purpose maize genotypes M.Sc. (Ag.), Thesis, Tamil Nadu Agricultural University, Coimbatore.

Singh, P. and Narayanan ,S. S. (1993). Biometrical techniques in plant breeding. 1st Ed. Kalyani publishers, New Delhi.

Suneetha, Y.; Patel, J.R. and Srinivas, T. (2000). Studies on combining ability for forage characters in maize. Crop Res. 19 (2): 266-270.

Vencovsky, R. and Barriga, P. (1992). Genetic biometrica no fitomelhoramento. Sociedade Brasileira de Genetica, Ribeirao Preto, 496 pp. 